\title{
АДВОКАТУРА: ІСТОРІЯ СТАНОВЛЕННЯ
}

\section{Бандурка Сергій Сергійович - доктор філософії, адвокат АО «Креденс» (Київ, Україна)}

DOI 10.32782/LAW.UA.2021.4.2

Адвокатура у суспільстві сприяе пробілактиці порушень прав та законних інтересів суб'єктів, будучи однією із правових механізмів, якій належить провідна роль у забезпеченні прав людини. У cm. 10 Загальноӥ деклараціи прав людини (прийнята Генеральною Асамблеєю ООН 10 грудня 1948 року) [1] гарантується право кожної особи на те, щоб у разі пред'явлення обвинувачення його провадження було розглянуто гласно та з дотриманням усіх вимог справедливості незалежним та неупередженим судом.

Сенсом та метою існування адвокатури як інституту професійного захисту та представництва є надання юридичної допомоги всім, хто такої потребує. Адвокати, як зазначав дореволюиійний історик права Д.Н. Бородін, - це фахівиі, правознавці, які захищають на суді права індивідуальних осіб в ім'я та на користь суспільного блага [2, с. 70].

Рівень розвитку адвокатури виступає індикатором стану демократї у суспільстві, одна із ознак захищеності прав людини. Економічна та процесуальна свобода кожного адвоката - це не лише основа «сильної» адвокатури, а й успішного захисту прав $i$ свобод людини та громадянина. Розвиток в Украӥні сочіально-економічних $i$ політичних відносин супроводжується використанням історичного досвіду проведення адвокатсъкої діяльності попередніми поколіннями. Вивчення та аналіз становлення адвокатури надасть змогу порівняти нині «чинну» діяльність адвокатів та виявити їі недоліки, що сприятиме подальшо- му розвитку надання кваліббікованої допомоги щзодо захисту прав і свобод людини та громадянина.

Ключові слова: адвокат, захисник, адвокатсъка діяльність, громадянин, права.

\section{Постановка проблеми}

Однією 3 характеристик державних та правових інститутів 6 їхня динамічність. При досить тривалому існуванні в історії будь-якого інституту можна назвати певні періоди його розвитку, отже, і розробити його періодизацію. Історія становлення адвокатури досить цікава тим, що багато інститутів дореволюційної адвокатури збереглися на наступних етапах правового реформування у радянський та пострадянський періоди. Особливо складними були переломні етапи ії становлення у межах нових зароджуваних соціально-економічних та політичних відносин.

Сьогодні саме адвокат став ключовою фігурою судової системи, оскільки саме він має найбільшу довіру громадської думки. Інтерес до проблеми становлення адвокатури багаторазово зріс у зв'язку з переходом України до побудови демократичної правової держави. Адвокатська діяльність є запорукою в дотриманні та зміцненні законності, яка зумовлюється вивченням історичного досвіду становлення та проведення такої діяльності з метою вдосконалення сучасного інституту адвокатури. 


\section{Стан дослідження проблеми}

Історичним дослідженням становлення та розвитку адвокатури займалась низка вчених різних періодів іiі існування. Серед таких вчених є Е.В. Васьковський, М.Д. Чубатий, М.М. Михеєнко, В.П. Шибіко, С.Ф. Сафулько, І.Ю. Гловацький Т.В. Варфоломєєва, Д.П. Фіолевський, О.Д. Святоцький, В.В. Медведчук та інші. Ці вчені досліджували розвиток адвокатури у минулі періоди іï життєдіяльності, враховуючи деякі зміни у національному законодавстві України, виникає необхідність додаткового дослідження становлення та розвитку адвокатської діяльності.

Мета дослідження полягає у дослідженні та аналізі історичного досвіду становлення та розвитку інституту адвокатури.

\section{Наукова новизна дослідження}

Адвокатура - інститут громадянського суспільства. Вона є професійною спільнотою адвокатів і як інститут громадянського суспільства не входить до системи органів державної влади та органів місцевого самоврядування. Адвокатура виконує правоохоронну та правозахисну роль, вона може оцінювати діяльність органів слідства, прокуратури, суду з точки зору законності, обгрунтованості, справедливості, гуманності. На теперішній час в Україні проводиться реформування правоохоронної, судової системи, крім того, вносяться зміни у чинне законодавство України, що обумовлює й удосконалення інституту адвокатури 3 урахуванням попереднього історичного досвіду його становлення та розвитку.

\section{Виклад основного матеріалу}

На цьому етапі розвитку правової держави в Україні одним із найважливіших питань $є$ вдосконалення інституту адвокатури.

Слово «адвокатура» походить від латинського кореня «advokare», «advokatus» («закликати», «запрошений»). На перших ступенях юридичного розвитку людського суспільства адвокатура і близько не була схожою на сучасну адвокатуру, існуючу у європейських народів.
Адвокатура - це соціальний інститут, який виник не відразу, а спочатку виник у вигляді незначної структури суспільства, яка при певних умовах сформувалася і досягла розквіту [3, с. 12].

Згідно з ч. 1 ст. 2 Закону України «Про адвокатуру та адвокатську діяльність» адвокатура України - недержавний самоврядний інститут, що забезпечує здійснення захисту, представництва та надання інших видів правової допомоги на професійній основі, а також самостійно вирішує питання організації і діяльності адвокатури в порядку, встановленому цим Законом [4].

Вважається, що адвокатура - організація, що включає на добровільній основі об'єднання громадян (професіоналів у галузі права), завдання якої - оберігати в установленому законом порядку права громадян на досудовому слідстві, дізнанні, у суді у кримінальних провадженнях, крім того, здійснювати представництво інтересів позивачів та відповідачів у цивільних справах. Таке розуміння інституту адвокатури було не завжди.

А.Г. Кучерена вважає, що адвокатура в різні роки існувала в усі часи і в усіх народів [7, с. 16]. Натомість, Є.В. Васьковський зазначає, що проходили тисячоліття, розросталися сильні цивілізації із зачатків патріархального побуту; видавалися закони, влаштовувалися суди, писалися книги про правознавство та управління державою, але не засновувалися адвокати [8, с. 9]. I.C. Яртих вказує на те, що адвокатура в сучасному розумінні цього явища виникла як публічно-державний інститут у стародавньому Римі в період розквіту першої Римської республіки, верховенство прав і закону. Адвокатура стала тим інститутом, без якого, на думку суспільства і держави, неможливе здійснення справедливого судочинства [9, с. 315].

Становлення інституту адвокатури прослідковується ще в античних країнах Середземномор'я таких, як Греція та Рим. Так, у Греції, хоча офіційного статусу адвокатів не існувало, утворився особливий клас осіб, які присвятили себе складанню промов для виголошення їх позивачами у суді. 


\section{Теорія, історія держави і права, конституційне право}

Демократичний устрій античної Греції створював сприятливі умови для виникнення адвокатури. Вважалося честю для кожного вільного громадянина полісу вміти себе захищати в суді.

У Греції не було ні державного обвинувачення, ні державного слідства. Антична держава брала на себе обов'язок арбітра у спірних питаннях, залишивши ініціативу обвинувачення у приватних руках; самі сторони мали збирати докази й аналізувати їх у своїх промовах. Афінське судочинство вимагало, щоб сторони особисто виступали в суді на свій захист. 3 цих причин виникла потреба в логографах — людях, які допомагали складати тексти промов. Згодом суд дозволив, щоб поряд із стороною ще й виступав інший громадянин.

Низка вчених, аналізуючи історичний огляд, прослідковує становлення та розвиток адвокатури в Україні з IX-XIII ст. - за часів Київської Русі - ця захисна діяльність у судах носила громадський (товариський) характер, така «юридична» допомога не була професійною. Роль захисників у суді виконували рідні та друзі сторін, «послухи» (свідки обвинуваченого), «видоки» (свідки вчиненого стороною або спірного факту). Таким чином, уже за найдавніших часів у кримінальному та цивільному процесі підсудний або тяжущі самі захищали свої інтереси. Одночасно «на їх захист» могли виступати одноплемінники, односельці, сусіди та інші особи. Діяльність подібного роду захисників у кримінальному процесі та у цивільних справах не регламентувалася. Повіреним у таких справах у судах міг бути будь-хто, за винятком осіб, яким це прямо заборонялося (малолітні, священнослужителі, чиновники в місцях їх служби, зганьблені судом тощо).

Інші вчені вважають, що адвокатура зародилась за часів польсько-литовської доби (XIV-XVI ст.), де вже адвокатську діяльність розглядали як професійне надання юридичної допомоги. У цей період звичаєве право витісняється писаним законом у містах та загальнодержавних судах, де запроваджується магдебурзьке (німецьке міське) право (XV ст.). Справа судового захисту у міських та загальнодержавних судах цього часу набуває професійного характеру. За часів польсько- литовської доби на перший план як захисник виступає прокуратор [10, с. 10]. Широко поширена думка, що вітчизняна адвокатура зародилася у листопаді 1864 року одночасно з правовою реформою в Російській імперії.

Сучасна територія України протягом майже всього свого історичного розвитку була розділена між різними державами, що відобразилося на формуванні політичних систем, структур влади та громадського життя на цих територіях. Це повною мірою стосується також історії створення і розвитку інституту української адвокатури, яка діяла в різні історичні періоди у Великому князівстві Литовському, Польщі, царській Росії, Австроугорській імперії та в СРСР [5].

У сучасному інтрепіюванні поняття «адвокатської діяльності» прийнято розуміти як надання професійної, кваліфікованої, юридичної допомоги, то доцільно досліджувати період становлення та розвиток інституту адвокатури в Україні саме тоді, коли їі розглядали саме як професійну та яка мала своє нормативно-правове закріплення.

Т. $\curlywedge$. Геведзе розподіляє на чотири періоди становлення та розвитку інститут адвокатури в Україні:

1) розвиток інституту адвокатури в період польсько-литовської доби (XIV-XVI ст.);

2) розвиток інституту адвокатури після судової реформи 1864 року;

3) радянський період розвитку інституту адвокатури (1917-1991 рр.);

4) інститут адвокатури в незалежній Україні [6].

За часів польсько-литовської доби мали чинність такі нормативно - правові акти: Статути Великого Князівства Аитовського (у всіх його редакціях 1529, 1566 та 1588 років), які діяли на українських землях до 1840 року (на території Київської, Подільської та Волинської губерній) та 1843 року (на Аівобережній Україні).

Професійна адвокатура в Україні сформувалася в період польсько-литовської доби. Особливу роль у цьому плані відіграли Литовські статути і Магдебурзьке право. Згідно з цими документами, захисником могла бути людина, яка добре обізнана 3 писаним правом, - тобто професійний юрист. Отже, звідси можна 
вважати і час народження професійної адвокатури, хоча момент іiі організаційного оформлення ще був віддалений у часі.

У Першому Статуті Великого князівства Аитовського (1529 р.) застосовуються терміни «заступники» та «прокуратори». Про заступників, зокрема, йдеться в арт. 8 (про заміну в процесі однієї особи іншою), тоді як арт. 9 (про прокуратора) Розділу 6 (про суддів) застосовується відповідно інший термін. Що стосується розмежування зазначених термінів, то заслуговує на увагу думка M.P. Аракеляна, який вказує на відсутність чітких меж між «заступником» (арт. 8) та «прокуратором» (арт. 9). Тільки при ретельному аналізі вказаних артикулів та судових справ можна побачити цей кордон: послугами першого користувалися родичі, хворі та немічні люди, послугами іншого - заможні шляхтичі. Така нечіткість у регламентації правового статусу прокуратора не визначає його відповідальності за програну справу. Однак ця відповідальність простежується у забороні бути прокуратором особі, яка не має осілості, тобто земельних володінь у Великому князівстві Аитовському, і з якої у разі програшу справи нічого стягнути [11, с. 105]. Отже, ця норма дає підстави говорити про прокуратора як спеціаліста, для якого заступництво стало професією та послуги якого стали платними, тобто мова йде фактично про адвоката у сучасному його розумінні.

У Другому Статуті Великого князівства Аитовського (1566 року) судовому представництву присвячені артикули 31-37 Розділу 4 (Про суддів та суди), де вже досить чітко розмежовані статуси заступника як уповноваженої особи відповідача в суді, так і прокуратора (професійного представника особи). Так, у арт. 32 Розділу 4 Статуту 1566 року зазначається, що якби хтось за позовами або не міг на суді бути як через хворобу, так і через деякі причини та потреби своїми; тоді прокуратора чи уповноваженого свого може замість себе у справі мати [12, с. 256-316].

Третій Статут Великого князівства Аитовського (1588 року) найбільш детально встановлюе порядок судового захисту. У арт. 56 йшлося про необхідність отримання письмового доручення на ведення справи прокуратором, яким визначало межі його повноважень, крім особистої присутності сторони (арт. 57). Артикул 58 передбачав низку вимог, яким повинен відповідати прокуратор. Арт. 57 закріплював норму про обов'язкове призначення прокуратора незаможним та сиротам [13].

Другий період становлення та розвитку інституту адвокатури - 20 листопада 1864 24 листопада 1917 роки - дореволюційний період історії адвокатури на українських землях. 20 листопада 1864 року відбулося підписання імператором Олександром II Судових статутів (Установи судових установлень, Статуту цивільного судочинства, Статуту кримінального судочинства, Статуту про покарання, що накладаються мировими суддями). В Установі судових установлень 1864 року містилися норми, що регламентують устрій інституту присяжних повірених, а також їх корпоративну організацію. У процесуальних кодексах - Статуті цивільного судочинства 1864 року та Статуті кримінального судочинства 1864 року - були закріплені норми, що регулюють діяльність адвокатів у цивільному та кримінальному процесі.

Слід зауважити, що термін «адвокат»не використовувався укладачами у Судових Статутах 1864 року. Замість нього вживалося поняття «присяжний повірений» (пізніше до нього додалося «приватний повірений»). I присяжний повірений, і приватний повірений - це неофіційна назва адвокатів, яка використовувалася і в науковій літературі, i в публіцистиці та серед населення.

Адвокати (присяжні повірені) здійснювали свою діяльність у трьох основних центрах (Санкт-Петербург, Москва та Харків). Здебільшого вони практикували самостійно, не входячи до складу юридичних консультацій.

Основні вимоги до адвокатів були наступні: 1) вища юридична освіта; 2) п'ятирічний термін стажування; 3) практика в одному із трьох центрів. Професійну діяльність адвокатів регулювали Судові Статути. Інститут присяжних повірених характеризувався такими ознаками: корпоративність, рівність, самоврядування, виражене в порадах та зборах присяжних повірених. 


\section{Теорія, історія держави і права, конституційне право}

Судова реформа 1864 року затвердила нові засади: самостійність судової системи, тобто суд відокремився від законодавчої та виконавчої влади, гласність та змагальність судового процесу, якому сторона захисту та обвинувачення отримала рівні права та можливості, залучення до правосуддя представників народу, попереднє слідство було відокремлено від прокуратури.

Дуже важливою зміною стало встановлення суду присяжних та заснування професійної адвокатури. Замість колишніх неписьменних, неосвічених хотадаїв прийшли добре освічені, сумлінні та прогресивно налаштовані адвокати.

24 листопада 1917 - 26 травня 1922 роки характеризуються хронодискретною паузою історії вітчизняної адвокатури. Цей період починається 3 моменту скасування дореволюційної адвокатури та триває до створення радянської адвокатури. 26 травня 1922 року постановою ВЦВК було затверджено Положення про адвокатуру, але оскільки воно лише в загальних рисах говорило про новостворені колегії захисників, то Наркомюстом 5 липня 1922 року приймає Положення «Про колегію захисників», відповідно до яких ці колегії утворювалися в кожній губернії при губернських судах, а нагляд за їх діяльністю покладався на суд, виконком та прокуратуру, куди без зволікання мали надсилатися стенограми всіх засідань колегій.

29 жовтня 1924 р. Постановою ЦВК СРСР були затверджені Основи судоустрою СРСР і союзних республік, де зазначалось, що для надання юридичної допомоги населенню засновуються колегії правозаступників. Так, у 1926 році Харківська губернська колегія захисників звернулася з пропозицією до РНК про те, щоб назву «колегія захисників» змінити на «адвокатура». 16 серпня 1939 року РНК СРСР затвердила Положення про адвокатуру СРСР. Ним були визначені завдання адвокатури, керівництво їі діяльністю, структура та порядок прийому та виключення 3 колегії адвокатів, дисциплінарна відповідальність. Положення вперше закріпило принцип, відповідно до якого адвокатською діялльністю мали право займатись лише особи, які мають юридичну освіту або не менше трьох років досвіду роботи в якості судді, прокурора, слідчого або юрисконсульта. Адвокатам заборонили поєднувати роботу в державних установах 3 роботою в адвокатурі.

У 1941 р. (у перший день війни) Президія Верховної Ради СРСР прийняла Указ «Про воєнний стан», судові справи передавались для розгляду військовим трибуналам. Адвокати не могли брати участь у таких справах, бо не було передбачена їх форма участі у воєнний стан. За воєнний період штат адвокатів значно скоротився. 3 березня 1953 р., із закінченням репресій, права адвокатів значно розширились, тим самим уряд тих часів підвищував законність у державі.25 грудня 1958 року були прийняті Основи кримінального судочинства Союзу РСР і союзних республік, у яких захисник допускався до участі у справі після закінчення попереднього слідства. Крім того, захисник мав право на зустріч з особою, яку він захищає, віч-на-віч.

20 квітня 1978 р. було прийнято Конституцію УРСР, у якій передбачалося, що для надання юридичної допомоги громадянам і організаціям діють колегії адвокатів. Це, вочевидь, потребувало створення нового законодавства про адвокатуру, а тому наступні два роки точилися дискусії з приводу розширення професійних прав і обов'язків адвоката, гарантій його діяльності, дисциплінарної відповідальності.

Важливим етапом розвитку радянської адвокатури стало прийняття першого i єдиного в СРСР Закону «Про адвокатуру в СРСР» 30 листопада 1979 р., який визначав організацію і порядок діяльності адвокатури в СРСР.

Положення про адвокатуру УРСР, затверджене Верховною Радою України 1 жовтня 1980 року, регламентувало діяльність колегій адвокатів республіки та розширило види юридичної допомоги, що надавалися громадянам. Колегії адвокатів в Україні формувалися за територіальним принципом. Створювалися обласні і Київська міська колегія адвокатів.

З 1991 року відповідно до Закону України «Про підприємництво» допускалося 
здійснення юридичної практики за ліцензією, яка видавалася Міністерством юстиції особам, котрі мають юридичну освіту. Згідно з чинним законодавством в Україні в цей час до участі в ролі захисників допускалися близькі родичі, законні представники, а також інші особи.

Наступним етапом у сучасній історії української адвокатури стало прийняття 19 грудня 1992 року Верховною Радою України Закону «Про адвокатуру». Новий закон відводив адвокатурі чільне місце, маючи на меті встановити престиж цієї професії, іiï історичні традиції, піднести роль у суспільстві як одного з гарантів забезпечення конституційних прав і свобод громадян.

5 липня 2012 року Верховна Рада України прийняла Закон України «Про адвокатуру та адвокатську діяльність», який має чинність по теперішній час. Цей Закон України був створений на підставі дослідження та аналізу історичного досвіду ставлення та розвитку інституту адвокатури у різні періоди, з урахуванням міжнародних норм та реформування органів виконавчої та судової влади. Закон України «Про адвокатуру та адвокатську діяльність» містить відносно детальні положення, що стосуються принципів організації адвокатури та гарантій іiі незалежності, та структурних підрозділів адвокатських спільнот.

\section{Висновки}

Історія адвокатури України, безперечно, знайшла своє відображення в новому Законі «Про адвокатуру та адвокатську діяльність». Адвокатура є тим правовим інститутом, який покликаний на професійній основі забезпечувати захист прав, свобод та інтересів фізичних та юридичних осіб. Забезпечення права на захист та приведення процесуальних норм, що регулюють це забезпечення, у відповідність до принципів міжнародного права, закріплених у Конституції України, а також кращими історичними традиціями вітчизняної адвокатури, $є$ одним із пріоритетних завдань юридичної спільноти.

\section{Мітература}

1. Загальна декларація прав людини. URS: https://zakon.rada.gov.ua/laws/ show/995_015\#Text (дата звернення: 29.11.2021).

2. БородинД.Н. Исторический очерк русской адвокатуры. - Пг., 1915. - С. 70.

3. Історія адвокатури України [Текст]/ Спілка адвокатів України, Академія адвокатури України. - Київ : СДМ-Студіо, 2002. 286 c.

4. Закон України «Про адвокатуру та адвокатську діяльність». Відомості Верховної Ради (ВВР), 2013, № 27, ст.282.

5. М. Петрів Історія української адвокатури в Польщі: союз українських адвокатів у Аьвові в 1923-1940p.p. // [Електронний ресурс] : Віртуальний офіс адвоката Михайла Петріва. - Режим доступу: http://www.petriv. com.ua/ua/files/union/union5.pdf. - Назва 3 екрану. - (Дата звернення: 29.11.2021).

6. Геведзе Т.А. ІСТОРИЧНИИ ГЕНЕЗИС ІНСТИТУТУ АДВОКАТУРИ В УКРАЇНІ. Науковий вісник Ужгородського національного університету, 2012. URS: $\quad$ https://dspace.uzhnu.edu.ua/jspui/ bitstream/lib/17084/1/\%d0\%86\%d 1\%81\%d 1 $\% 82 \%$ d0\%be\%d $1 \% 80 \%$ d0\%b8\%d $1 \% 87 \%$ d0\% bd\%d0\%b8\%d0\%b9\%20\%d0\%b3\%d0\%b5\%d 0\%bd\%d0\%b5\%d0\%b7\%d0\%b8\%d 1\%81\%20 $\%$ d 1\%96\% d $0 \%$ bd $\%$ d $1 \% 81 \%$ d $1 \% 82 \%$ d0\%b8\%d 1\%82\%d 1\%83\%d 1\%82\%d 1\%83\%20 $\%$ d0\%b0\%d0\%b4\%d0\%b2\%d0\%be\%d0\%ba\% d0\%b0\%d 1\%82\%d 1\%83\%d 1\%80\%d0\%b8\%20 $\%$ d0\%b2\%20\%d0\%a3\%d0\%ba\%d 1\%80\%d0\%b 0\% $1 \% 97 \% \mathrm{~d} 0 \%$ bd\%d 1\%96.pdf (дата звернення: 29.11.2021).

7. Кучерена А.Г. Роль адвокатуры в становлении гражданского общества в России: автореф. дис. ... докт. юрид. наук : спец. 12.00.11 «Судебная власть, прокурорский надзор, организация правоохранительной деятельности, адвокатура» / А.Г. Кучерена. - М., 2002. - 44 с.

8. Васьковский Е.В. Организация адвокатуры: в 2 ч. / Е.В. Васьковский. - С.-Пб.: Н.К. Мартынов, 1893. - Ч. 1 : Очерк всеобщей истории адвокатуры. -621 с.

9. Яртых И.С. Адвокатура и гражданское общество : монография / И.С. Яртых. Ульяновск: Областная типография «Печатный двор», 2007. - 336 с.

10. Святоцька В.О. Інститут адвокатури України: становлення та розвиток: автореф. дис. ... канд. юрид. наук : 12.00 .01 «Теорія та історія держави і права; історія політичних 


\section{Теорія, історія держави і права, конституційне право}

і правових учень» / В.О. Святоцька. - $\mathcal{A}$, 2010. - 20 c.

11. АРАКЕЛЯН, М. Развитие института судебного представительства в Великом княжестве Аитовском. Наукові праці Одеської національної юридичної академії, 2009, т. VIII, с. 105.

12. КІВАЛОВ С., МУЗИЧЕНКО П., ПАНЬКОВ, А. Статути Великого князівства Аитовського: у 3-х т. Т. I: Статут Великого князівства Литовського 1529 року. Одеса: Юридична література, 2003, с. 246.

13. LE BERQUIER, J. Le barreau moderne, français et étranger [Електронний pecypc]. 2-e éd. Paris: Marchal, Billard, 1882. Peжим доступу: https:/gallica.bnf.fr/ark:/12148/ bpt6k94645d/f16.image (дата звернення: 29.11.2021).

\section{ADVOCACY: THE HISTORY OF FORMATION}

Advocacy in society contributes to the prevention of violations of the rights and legitimate interests of subjects, as one of the legal mechanisms, which has a leading role in ensuring human rights. In Art. 10 of the Universal Declaration of Human Rights (adopted by the UN General Assembly on December 10, 1948) [1] guarantees the right of every person to have his or her proceedings heard openly and in compliance with all requirements of justice by an independent and impartial tribunal.

The meaning and purpose of the bar as an institution of professional protection and representation is to provide legal assistance to all who need it. Lawyers, as noted by the prerevolutionary historian of law DN Borodin are specialists, jurists who defend in court the rights of individuals in the name and for the benefit of the public good [2, p. 70].

The level of development of the bar is an indicator of the state of democracy in society, one of the signs of human rights protection. The economic and procedural freedom of every lawyer is not only the basis of a "strong» bar, but also the successful protection of human and civil rights and freedoms. The development of socio-economic and political relations in Ukraine is accompanied by the use of historical experience of advocacy by previous generations. The study and analysis of the formation of the legal profession will make it possible to compare the current «current» activities of lawyers and identify its shortcomings, which will further develop the provision of qualified assistance to protect human and civil rights and freedoms.

Keywords: lawyer, defender, advocacy, citizen, rights. 